Historic, Archive Document

Do not assume content reflects current scientific knowledge, policies, or practices. 


The Dahlias and Gladioli I have to offer this year are better than any ever listed before. In size, color, length of stem and freedom of bloom they cannot be excelled, and to bring my selection up to a standard so that any one of them will give satisfaction, have listed one hundred of the best Dahlias and twenty-five of the best Gladioli grown, all of which have been tried out and the others discarded. This will insure to you a collection that will give satisfaction, as selecting from catalogues that list a great many old, inferior varieties, one seemingly being better than the other, only confuses, and in the end you receive unsatisfactory varieties. To aid you in growing these flowers in the right way, there is embodied in this booklet a set of cultural directions, which if followed will give flowers of exceptional merit. 



\section{THE DAHLIA}

Classification of Dahlias :

Cactus : Petals are long, twisted, and terminating in a point.

Some petals are straight, others incurved.

Peony-flowered : The flowers are large, usually semi-double.

Decorative : Petals are long, broad, flat and nearly straight.

Show : The flowers are large, round, quilled and well formed.

Location : It is better to plant in an open sunny location, although an occasionally shaded spot will give equally good results.

Soil : Any soil will do if you will follow instructions noted below.

Preparation : Dig the ground ten to twelve inches deep in the Fall of the year if possible. This is not absolutely necessary but gives excellent results. As soon as the ground can be worked in the Spring dig ten to twelve inches deep as often as you can, the oftener the better, as by doing this you thoroughly incorporate the fertilizer with the soil and your ground will be better pulverized.

Fertilizer : Immediately after digging your ground in the Fall place over same well rotted cow manure at the rate of one hundred pounds to one hundred square feet of ground surface. If the digging is put off till Spring, put over where you intend to dig cow manure as mentioned above, and over this for each one hundred square feet of ground surface, one pound of nitrate of soda, one pound of potash, two pounds of phosphate and fifteen pounds of air-slacked lime, distributing evenly, and thoroughly dig in as outlined under "Preparation." Use the cow manure every two years, the lime every four years, and the other three every year.

Planting : Any time from May 5th to July 1st will be all right. Only plant a single bulb and never the whole clump. Dig hole ten to twelve inches deep and plant the bulb flat with the eye, or sprout, pointing upwards, on well pulverized soil that has been replaced in the hole so that the bulb will be five or six inches from the top of the ground. This will give loose soil for the root action. Firm the soil well around the bulb, but only 
slightly press the soil above it. Give growing space of from two to four feet each way for each plant. Never allow more than one stalk to grow to each bulb. When a plant first appears above the ground take a stiff piece of cardboard four inches high and encircle the plant as near to it as possible, pressing board about one inch in the soil, for by doing this it will prevent loss of the plant through being destroyed by the cut worm.

Cultivation : This is a very important matter. Keep the soil well stirred with the rake. By doing this no weeds can grow and soil will not crust. Do this the depth of the teeth at least once a week if possible, and a slight stirring after each rain. When the buds are about to break open only slightly stir, otherwise by going deep you will break the flowering roots which grow near the surface of the ground at that time.

Staking: Before planting the bulb place about three inches back of it a stake which will be about four feet out of the ground after firming it in the soil. When the plant is one foot high tie the stalk to this stake with a piece of cord or other material that will not cut the plant, doing this every extra foot of growth, as by so doing your plant will be protected from being broken by winds and heavy rain falls.

Trimming : To get large flowers this is absolutely necessary. When the plant has attained a height of say two to four feet, trim out, cutting off all branches up to one foot from the ground and cutting off near the stalk the weaker branches and others excepting six of the strongest, care being used not to leave the branches all on one side of the stalk or too near each other.

Disbudding : This must also be done to get large flowers. After you have decided on the branches you will keep mentioned under "Trimming", you will notice all along the branches leaf growth. Where the leaf growth starts from the branch is where the buds appear. As a general rule three buds appear at the same time side by side, the strongest one you retain, cutting or breaking off the others, and doing this here and there all along the branch.

Mulching : When the buds are of good size spread over every part of the ground and between the plants a layer of about three inches of stable manure. It is better to thoroughly wet the ground before placing on as mulching is done to keep moisture 
in the ground as well as to protect the small flowering roots from being destroyed by the hot sun or being broken by walking on them.

Watering : Dahlias like water, but this will not be so necessary if you cultivate thoroughly. However, when you water soak the ground well, otherwise the roots will come to the surface and probably be destroyed.

Manure Water : Take any clean barrel (not oil or brine), that will hold water and fill about one-quarter full of sheep or well rotted cow manure and fill with water. Stir night and morning for about a week. If your flowers begin to grow smaller during the year it is because there is not enough food in the soil, at which time take about a quart or two of this water and apply to each plant. When you have used the water in the barrel again fill with water and stir as before. Use only after a heavy rain or a thorough wetting of the ground.

Cutting and Keeping of Bloom : Cut the flowers in the early part of the day or at night, for if cut in the hot sun they will soon wilt. To keep bloom for a longer time than could be had ordinarily have a vessel handy containing water as hot as the hand can stand it, and as you cut the flowers plunge the stems nearly the whole length in this water, care being taken that the leaves or flowers do not touch the hot water, and leaving in the water until it cools.

Harvesting and Storing : After the foliage has been blackened by frost cut the stalk to within six inches of the ground. Dig up carefully on a sunny day in the early morning, and place the clump so that it rests on the cut stalk, the bottom pointing upward so that the sun can cure the bulbs. This must be done on a day that the bulbs will not be touched by frost. Before evening store in a dry, cool place where the thermometer will range from 40 to 55 degrees and sprinkle with air slacked lime.

Division of Clumps : If your clumps are not showing eyes, or shoots, the latter part of February put same in a warm place and cover with newspaper. Dampen the paper down and keep damp. The shoots appear where the bulb is attached to the stalk, and by taking a sharp knife separate the bulb with the sprout from the stalk, after which sprinkle the cut part of the bulb with airslacked lime to stop bleeding. 


\section{CACTUS VARIETIES}

Atlanta : Creamy-white flower of large size, having long stems and is a free bloomer. ..........................

Aurora : Apricot, suffused flesh pink, lighter at the tips. Flowers are large and bloom freely .................. 20 c

C. E. Wilkins : Salmon pink overlaying yellow. Flowers are large and of a fine color. Very free bloomer. .......... 25c

Conquest : Crimson-maroon flowers of large size, incurved formation having long stems. A good bloomer. ........ 35c

Countess of Lonsdale : Salmon pink and amber. Flowers are of good size, having long stems. It is a very free bloomer. . . 15c

Dainty : Center lemon yellow, delicate rose pink tips. Flowers of medium size but very pretty. ............... 15c

Dr. Roy Appleton : Light lemon yellow, slowly changing and deepening to light salmon near the tips, which again assume the basal color. Flowers large and free.

$25 \mathrm{c}$

Emu : Dark crimson shading to rose at base. Very large, of finest exhibition shape, erect habit. Very good. Pot Roots. ... 50c

Etendard De Iyon : Rich carmine-rose. The flowers are very large, having long stems and is a fine exhibition variety. One of the largest ..............................

Extrase : Mauve-rose which gradually passes to a white center. Flowers are large and stems long $\ldots \ldots \ldots \ldots \ldots \ldots \ldots \ldots$

Fireworks : Ground color is yellow, same being spotted and striped with red. Flowers are large and stems long ......... 30c

Frederick Wenham : Warm fawn pink, with soft salmon at the center. Flowers very large of incurved formation. Pot Roots. 35c

Gaillard : Bright vermilion red. Flowers are of good size, the petals being slender. Stems long. ...............

Goldland : A fine yellow variety of good size, blooming freely on

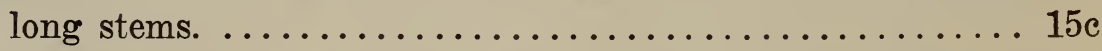

Golden Eagle : Bright yellow with suffusion of rose and fawn. Flowers are large on very good stems $\ldots \ldots \ldots \ldots \ldots 25 \mathrm{c}$

Golden Gate : Deep golden yellow, tinted brown or russet. Flowers exceptionally large, borne on long stems. This is one of the best grown. Be sure and try it. ............... $35 \mathrm{c}$ 
H. L. Brousson : Center white, shading to deep rich rose. Flowers large. This variety should be given a trial ........ 25c

Irresistible : Yellow, suffused rose. Flowers very large. This is an ideal flower and becoming very popular ......... 25c

J. H. Jackson : Deep, rich, velvety maroon. The flowers are large and stems long. A splendid flower .............. 15c

Johannesburg : Bright gold. Flowers very large, free and of splendid form and long stems. Should be grown by every-

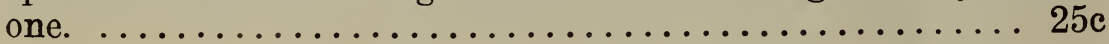

Jupiter : Ground color pink, with distinct yellow base, and the whole striped and splashed with crimson. Very good size. . 25c

Kalif : Scarlet, well formed flower, of massive size, on stout, erect stems. This is probably the largest grown ........ $75 \mathrm{c}$

Mad. Henry Cayeux : Delicate rose flesh pink with white tips, center of bloom pure white, flowers large, stems long ....... 25c

Marguerite Bouchon : Brilliant rose pink tipped white, with light pink center. Flowers are very large and greatly admired. It

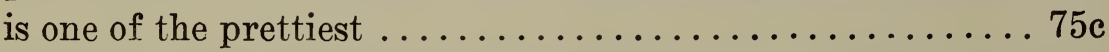

Miss Stredwick : Soft yellow at the base, quickly changing to deep pink with a lighter shade at the tips. Flowers large and stems

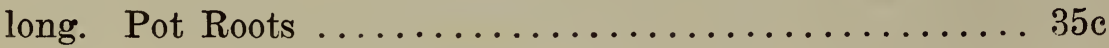

Mrs. Alfred Dyer : Lemon yellow center shading to rose pink, large, full, fine shaped flower. Pot Roots ............ 50c

Mrs. Brandt : Salmon buff shading to yellow center, Bold, massive flower. Good habit. Pot Roots .............. 50 c

Mrs. Douglas Fleming : Pure white. Very large, full and very fine. This is indeed a grand flower. Pot Roots ......... 50 c

Mrs. F. Grimstead : Deep rich purple crimson flower of large size, having long stems and being a free bloomer. ........ 15c

Mrs. Stephens : Primrose yellow of a very beautiful color. Flowers large, stems long and a very free bloomer ......... 35c

New York : Orange yellow in center, shading off to rich bronzy salmon. Flowers very large, having good stems ........ 30c

Phoenix : Dark velvety maroon, center striped scarlet. Flowers large, stems long and substance good ........... 25c

Queen of Hearts : Pure white shading to lemon yellow at base of petals. Flowers large, stems long and a free bloomer. Very pretty. .............................50 
Red Admiral : Rich, fiery scarlet. This is a very large dahlia and at exhibitions it is very often seen $\ldots \ldots \ldots \ldots \ldots \ldots 2 \mathrm{c}$

Rene Cayeux : Rich, ruby crimson. Flowers are large on long stems. It is a very free bloomer. .............. $20 \mathrm{c}$

Rheinkonig : Pure snow-white flowers of good size, having long stems. A good bloomer .................. 20c

Richard Box : Bright canary yellow. Flowers large, stems long and rigid. Incurved variety and one of the best. Pot Roots $35 \mathrm{c}$

Ruth Forbes: A beautiful clear pink. Strong vigorous grower, very free, the flowers being large and stems long. ......20c

Snowdon : Pure white, large, bold, massive flower. A very free bloomer, on fine stems. Pot Roots ............. 35c

Stability: Pink variety of very good form and size. Its blooming qualities are of the best $\ldots \ldots \ldots \ldots \ldots \ldots \ldots \ldots \ldots \ldots \ldots \ldots$

The Earl : Rich ruby crimson, with silvery reverse. Large, incurved, exhibition variety. Pot Roots ......... 50c

Wodan : Salmon-rose color, of large size, long stems and freedom of bloom. A good variety $\ldots \ldots \ldots \ldots \ldots \ldots \ldots \ldots \ldots \ldots \ldots$

Wolfgang Von Goethe : Rich apricot with carmine shadings. Flowers large and well formed, having long stems ....... 25c

\section{PEONY - FLOWERED VARIETIES}

Avalanche : Pure snow white of very large size. The stems are of good length. This is a very fine variety $\ldots \ldots \ldots \ldots \ldots 75 \mathrm{c}$

Bertha Von Suttner : Blush rose, tinted salmon. Flowers large, being erect on long stems. It is very good ........ 25c

Chatenay : Color of the Chatenay rose. Flowers are very large, borne on long, wiry stems, well above the foliage ..... 50c

Dr. Peary : Deep mahogany. The flowers are very large and the stems long. An excellent variety $\ldots \ldots \ldots \ldots \ldots \ldots . \ldots .6$

Electra : Bluish mauve. Grows very erect above the foliage. Free flowering. Stems long and flowers large ......... $30 \mathrm{c}$

Engineer : Beautiful bright lake, suffused yellow. Flowers large on

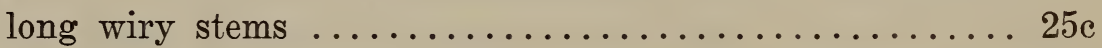

Geisha : Rich combination of scarlet and gold. Flowers very large on long stems. A great favorite ............ 35c 
Glory of Baarn : Delicate flesh pink of large size, having a long stem and a free bloomer. Very good .......... 20c

Hon. R. L. Borden : Rich, golden bronze. Flowers are large. It is a free bloomer and very attractive. ........... 25c

Hortulanus Budde : Scarlet. Very free flowering variety on long stems. A new and good addition. ............. 25c

King Leopold : Primrose, shading lighter at the edges. Flowers are of good size, stems long and a free bloomer. ........ 25c

Liberty : Scarlet crimson. Flowers large and of fine habit. A beautiful flower. Pot Roots ................ 50c

Mad. Van Loon : Scarlet variety of very good size, stems being very long. A very free bloomer $\ldots \ldots \ldots \ldots \ldots \ldots \ldots \ldots \ldots \ldots$

Mont Blane : Pure white. Flowers very large on good stems. An exhibition variety of the highest quality. ......... $75 \mathrm{c}$

P. W. Janssen : Orange salmon. Flowers large and stems long. A very good variety. ....................

Queen Emma : Distinct soft rose. Flowers are of good size. It is

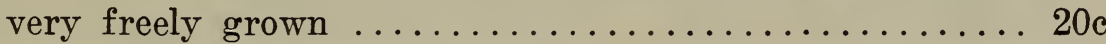

Queen Wilhelmina : Beautiful white with yellow center. Immense fluffy flowers on long stems $\ldots \ldots \ldots \ldots \ldots \ldots \ldots \ldots \ldots \ldots$

Rembrandt : Apple blossom pink. Flowers very large on good stems. This is a very good bloomer. Pot Roots ......50c

Selma : Rosy-pink variety of large size, long stems and a very free bloomer. A good flower .................... 35c

South Pole : White. This is a large double flower and a very good bloomer. It is one of the best. Pot Roots .........50c

Titian : Rose shaded. Flowers very large and one of the finest. It is very beautiful. Pot Roots .............. 50c

\section{DECORATIVE VARIETIES}

Alice Roosevelt : Cream white, slightly tinged lavender. It is a very good bloomer, the stems of which are long. ....... 25c America : Orange and apricot. Flowers are large, stems long, and a very good bloomer. ....................... Augusta Nonin : Bright red. Flowers are very large. It is a very good addition to any ones collection. 
Berch Von Heemstede : Pure yellow, free flowering, very large variety having long stems. Very good. ........... $75 \mathrm{c}$

Delice : Deep pink. Flowers large and stems long. One of the most popular Dahlias grown today. ............... 20c

Forbes Le Colosse : Pure yellow. The flowers are exceptionally large and of excellent formation. ..................

Golden West : Bright canary yellow. The flowers are large, stems long and a very good bloomer. .............. 25c

Hortulanus Fiet : Shrimp pink. One of the largest of the Decorative class. At exhibitions it carries off the prizes. . . . . $75 \mathrm{c}$

Jack's Discovery : White mottled violet rose. The flowers are large. The color and size makes this variety very popular .... 25c

Jeanne Charmet : Violet rose on lighter ground. Flowers large, stems long and a very free bloomer . . . . . . . . . 20 c

Le Grand Manitou : White spotted and striped, blotched reddish violet. Occasionally blooms pure violet. Flowers very large, a free bloomer with long stems. ............. $35 \mathrm{c}$

Leo XIII : Deep yellow. A very large, full and attractive flower on very long stems. It is indeed a beauty. ......... $75 \mathrm{c}$

Mad. Helen Charvet : Pure waxy white tinged with pink. Flowers of large size, having long, stiff stems. This is quite a favorite ...............................

Mad. Van Den Dael : Silver pink on white ground. Flowers are large, having long stems and is a very good bloomer. ....20 c

Mad. Victor Vassier : Clear sulphur yellow with no green center. Flowers large. An excellent yellow ............. 20c

Manitou : Yellow overlaid bronze. Very large flower. This is a variety which is appreciated owing to its size and color. . 50 c

Mrs. J. Gardner Cassatt : Deep rose. Flower is large, stems long

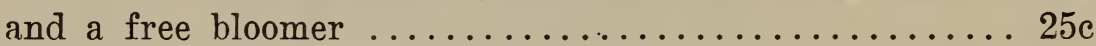

Mrs. Roosevelt : Silver rose. Flowers large. It is holding its own with the best and will do so for a long time .......20 c

Princess Juliana : White. A very free bloomer on very long stems, the flower being very erect and of good size. ....... 25c

Princess Victoria Louise : Bright rose pink. The flowers are of good size. It is a very free bloomer $\ldots \ldots \ldots \ldots \ldots \ldots$ 15c 
Professor Mansfield : A very beautiful combination of yellow, red and white. Flowers large and stems long. .......... 15c

Royal Purple : A purple sport of Le Grand Manitou. Flowers very large on long stems. .......................

Sebastopol : One of the finest of recent introductions. Flowers rich, bright orange, of good substance, borne on long, stiff stems. The flowers are large. ...................... 25e

Souvenir de Gustave Doazon : Crimson-red blooms of very large size. Free flowering. A very popular variety. ........ 15c

Yellow Colosse : Primrose yellow of large size, having long stems. A good cutting variety. ..................... 15c

Yellow Duke : Very pretty yellow flowers of good size. It is a free hloomer, having long stems. ................. 15

\section{SHOW VARIETIES}

Charles Lanier : Yellow amber, shaded buff. Large flowers on erect, stout stems .............................. 15c

D. M. Moore : Deep maroon. Flowers are very large, blooming freely on erect, stout stems. ................... $50 \mathrm{c}$

Dorothy Peacock : Large, bright clear pink flower having long stems. An early and continuous bloomer. ..........20

Ethel Maule : Large, snow white, lavender tinted center, dwarf growth; very free. ..................... 15

Gloire de Lyon : White. A very large flowering Dahlia, borne on long stems. The best white show. ............ 15e

Le Colosse : Red flowers of huge size, double and very erect. It is one of the best. Pot Roots ................. 50 c

Mad. Alfred Moreau : Rich, deep rose pink. A very large and free flowering variety. ....................

Rose : Rose color of large size. Flowers are full and are borne on long, stout stems. ....................... 25c

Wm. Dodds : A beautiful shade of yellow. The flowers are very large, having long stems. It is a free bloomer. ....... 15c

W. W. Rawson: White, overlaid with delicate lavender, tinted deeper at tips. Flowers very large, free and stems long. Its popularity is too well known to comment further ..... 25c Mixtures : My selection, $\$ 1.00$ a dozen. 


\section{THE GLADIOLUS}

Location, Soil, Preparation Fertilizer, Cultivation, Manure water, Mulching, are the same as for Dahlias.

Planting : Plant puckered side up from four to six inches deep and four inches each way. For succession of bloom plant from May 1st to July 1st.

Staking : To stake each Gladiolus would involve considerable labor. Place heavy stakes at each corner and every six feet on the sides of the beds, and by tying heavy cord from one stake to another, will prevent them from falling down.

Watering : Gladioli like water and plenty of it.

Harvesting : When the foliage has been killed by the frost dig up the bulbs in the morning and allow to cure in sun until evening, care of course being used not to allow them to be touched by frost. Store in a cool, dry place where the thermometer ranges from 40 to 55 degrees. Before storing cut off the foliage about one inch above the bulb.

Cut flowers : Cut in the evening if possible. Never cut any of the leaf growth but only the flowering spike, as by cutting the leaf it affects the bulb. Place the spike in a cool dark place during the night, and by taking off the dead flowers each morning and cutting off part of the stem they will flower until the top bud is reached, which usually takes a week or longer.

General Remarks : I have tried to make myself as clear as possible, but should there be anything you do not understand would be pleased to receive a letter from you, which, will have immediate attention, as I appreciate that upon your success and pleasure depends my success. 
3c Each, 30c Dozen, $\$ 2.00$ Hundred.

America : Beautiful soft pink, tipped with lavender. Flowers large.

Baron Hulot : Royal violet-blue. Flowers of good size on long spike. Halley : Salmon red. Flowers are very large. Spike long. A very pretty variety which is grown largely.

Mrs. Francis King : Light scarlet of a very pleasing shade. Flowers are very large and the spike long.

George Paul : Clear, deep, velvety crimson. Flowers of the largest size well arranged on long spike.

6c Each, 60c Dozen, $\$ 5.00$ Hundred.

Czar Peter : Wine red. Flowers are of good size, borne on long spike.

Empress of India : Dark brown black. Flowers large on long spike. You will like this flower.

Lily Lehman : Ivory white flowers of very large size. Somewhat the form of a lily.

Princeps : Rich, dazzling scarlet flower of the largest size, having a white blotch on the lower petals.

Willy Wigman : Creamy white with soft carmine blotch. Flowers very large and spike long.

9c Each, 90c Dozen, \$7.50 Hundred.

Glory of Holland : The finest white to date. Flowers large on good stems. You should give this variety a trial.

Golden Queen : Creamy buff with blotch of crimson. Flowers large. A beautiful combination of colors.

Kunderdi Glory : Creamy pink, with a most attractive crimson spot in center of each lower petal. Flowers are very large, very compact and the edges nicely ruffled.

Niagara : Cream shade blending to Canary yellow. Flowers are large and very compact.

Panama : Much deeper pink than America. Flowers large, compact and spikes strong. A pretty variety. 


\section{2c Each, \$1.30 Dozen, \$10.00 Hundred.}

Electra : Orange red. A beautiful color. Flowers large and spike tall. An exceptional fine variety.

Golden West : Bright orange red with a few darker stripes. Flow. ers very large on good spike.

Rosa Lindt : A light violet variety of exceptional large size and beauty, having long spikes.

15c Each, $\$ 1.50$ Dozen, $\$ 12.50$ Hundred.

Goliath : Dark violet. Flowers very large. A new and beautiful variety. Excellent in every way.

Liebesfeuer : Bright scarlet with a patch of salmon pink in the throat. Blossoms large and well opened.

Loveliness : Fine creamy white flower with very delicate markings. Flowers very large on very fine spike. It is one of the best.

Pink Perfection : Bright pink. Flowers very large, well opened, and the spike is straight and strong.

Queen Wilhelmina : Light pink with red blotch. Flowers very large on long spike. A beautiful variety.

Schwaben : Finest yellow to date. Flowers large and spike long. Very often five or six flowers open at the same time.

Sieger : Very attractive red of very large size having a long spike. It is very good in every way.

Mixtures : Consisting of named varieties $\$ 2.00$ a hundred. 



.
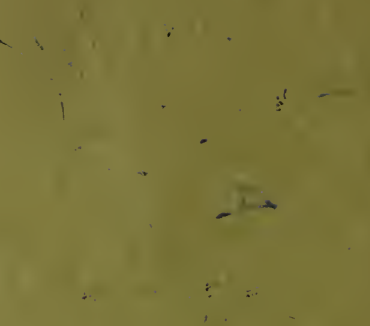